\title{
Abaixo as armas! $O$ discurso a favor da neutralidade no debate sobre a Primeira Guerra Mundial no Brasil (1914-1917)
}

Lívia Claro Pires*

Resumo: Em 1914, eclodiu na Europa a Primeira Guerra Mundial. Na conflagração entre as principais potências da época, os valores postulados pela Belle Époque foram postos em xeque. Do outro lado do Atlântico, longe do teatro de guerra, os intelectuais brasileiros sentiram o impacto do estado de beligerância e assumiram posturas buscando problematizar o conflito. $\mathrm{O}$ presente artigo propõe-se a analisar brevemente o discurso a favor da neutralidade no debate sobre a Primeira Guerra Mundial no periódico fluminense Jornal do Commércio, antes da entrada brasileira no conflito.

Palavras-chaves: Intelectuais - Primeira Guerra Mundial - Imprensa

Abstract: The First World War started in Europe in 1914. The conflagration between the major Power nations threated the moral values of Belle Époque. Although the Brazilians intellectuals were away from the theater of war, they felt the belligerency's impact and they assumed postures seeking to discuss the conflict. This paper intends to briefly analyze the discourse on the First World War in favor of the neutrality, at Jornal do Commércio, before the entry of Brazil in the conflict.

Key Words: Intellectuals - First World War - Press

\section{Introdução}

O autor deriva de um lugar social, categoria esta que define a apreensão da realidade que o circunda, e formas das quais utiliza para expressar-se ${ }^{1}$. Para ter sua posição de autoria e ideias legitimadas, o autor faz uso de vocabulários e conceitos, estabelecidos, dentre outros elementos, pelo lugar social a qual pertence. O texto é, assim, organizado de forma precisa.

Para além de sua vontade de legitimação, o autor possui uma determinada intenção ao escrever um texto. De acordo com Quentin Skinner, esta intenção contribui para imprimir um significado à linguagem utilizada (Cf. SKINNER, 2005). A intenção do autor em transmitir certa

\footnotetext{
* Mestre em História pela Universidade do Estado do Rio de Janeiro.

${ }^{1}$ A categoria lugar social foi extraída da análise de Michel de Certeau acerca da escrita historiográfica. Segundo o historiador, o corpo social e a função neste ocupada influenciam de maneira determinante a enunciação intelectual, da mesma forma que esta atua sobre a sociedade.
} 
mensagem, empregando um instrumentário legitimado por seu espaço social e ambientado em um cenário histórico, são alguns dos elementos que conferem singularidade a uma obra.

Dessa forma, não se pode inferir que os discursos sejam práticas naturalizadas. Eles são condicionados pela intenção do autor na prática da escrita e pelo sua posição na sociedade a qual pertence. A mensagem a ser transmitida pela produção intelectual configura-se, assim, como uma representação da realidade, buscando empreender o convencimento dos seus leitores.

Entre 1914 e 1917, os homens de letras alocados na Capital Federal, lançaram-se ao objetivo de analisar a Grande Guerra, utilizando os jornais como espaço de expressão. Os artigos publicados expuseram o conflito europeu sob a perspectiva do grupo social a qual pertenciam seus autores, isto é, os intelectuais. Utilizando-se dos arcabouços próprios dessa categoria, fossem as correntes de pensamento ou a linguagem característica da primeira década do século $\mathrm{XX}$, esses indivíduos intentaram o convencimento dos leitores da assertividade da sua representação a respeito da guerra que surpreendeu o mundo da Belle Époque.

\section{No tempo das certezas ${ }^{2}$}

Os primeiros anos do século XX foram enleados pelo que se convencionou chamar de Belle Époque ${ }^{3}$. Jardins floridos, cafés espelhados, multidões bem vestidas e piqueniques em bulevares compunham um cenário de beleza imperturbável. A modernidade poderia ser tocada com a ponta dos dedos nas lojas de roupas, nos chapéus franceses, nas máquinas de escrever; vista e ouvida nos teatros, cinematógrafos e fotografias. Na transformação dos hábitos cotidianos, na compra de produtos outrora ausentes das vendas, na adesão a novas formas de entretenimento, percebe-se a necessidade de consumir esse novo mundo propagandeado em revistas, jornais e cinemas, aderindo às novidades que prometiam facilitar, embelezar e, sobretudo, civilizar.

No Brasil, este último aspecto da época dourada foi o que prevaleceu. O sonho da civilização enleava o país recentemente tornado uma República, ansioso por superar o passado monárquico, escravista e mestiço. Atrelado à perspectiva do progresso, alcançar o status de nação civilizada era o último estágio da escala evolutiva em que se encontrava a humanidade e o mundo moderno. Através dos avanços tecnológicos, da prática cientista e da mudança cultural, a grande

\footnotetext{
${ }^{2}$ Esta expressão foi retirada do título do livro de Angela Marques da Costa e Lilia M.Schwarcz.

${ }^{3} \mathrm{O}$ termo Belle Époque, de acordo com Jacques Boudet, foi cunhado na década de 50 do século XX, caracterizando o entusiasmo pelo avanço tecnológico e pela efervescência intelectual dos anos que antecederam à Grande Guerra.
} 
nação dos trópicos poderia obter a sua redenção, conforme acalentava o desejo de suas elites políticas, econômicas e culturais, grupos sociais que usufruíam dos prazeres da Belle Époque. Presentes em diversas instituições da sociedade brasileira, coordenaram a tentativa de transformação material e espiritual ansiada.

O Estado republicano interceptou as atividades modernizantes e as tomou sob a sua jurisdição, utilizando os arquétipos da modernidade para legitimar a sua existência. Consonante com os anseios das elites, esta instituição incorporou a função de educadora e regulamentadora da sociedade. Obras para o desenvolvimento das infraestruturas urbanas, instalações de bondes e postes de luz elétrica configuraram alguns dos esforços para a melhoria do país e para a comprovação das diferenças qualitativas do regime deposto em 1889.

Não foram unicamente incrementos pontuais que os sucessivos governos republicanos realizaram nos primeiros anos do novo século. Iniciaram, por certo, um sistema de ações profundas. Obras públicas modificaram a paisagem das principais cidades do centro-sul do país, com o intuito de extinguir os últimos vestígios físicos dos tempos coloniais e monárquicos, e comprovar, pela estética urbana importada de Paris ou de Londres, a entrada do Brasil no rol das potências modernas e civilizadas.

As iniciativas para o embelezamento exigidas atingiram o cotidiano e o privado para garantir a mudança dos hábitos da população. Legislava-se para higienizar a nação, proibindo-se o cuspe em vias públicas, aprovando campanhas para a vacinação compulsória, distribuindo cartilhas instruindo o banho diário e derrubando cortiços insalubres. Desencadeava-se um processo civilizador, baseado em verdades científicas em voga na época, para enquadrar os costumes ditos populares aos padrões dos novos tempos e à imagem de país moderno e civilizado a ser levada ao exterior. No trato junto às camadas populares, a Belle Époque mostrou o seu lado menos sorridente e efusivo: a da desproporção entre a nação das elites ansiosas pela civilização, e a maioria da população mal informada e fora do alcance dos benefícios dos novos tempos.

O Rio de Janeiro tornou-se o emblema das alterações sofridas pelo país sob a insígnia da modernidade. Transformar a Corte do ultrapassado Império em Capital Federal da progressista República era uma prioridade do Estado recém-instituído. No quadriênio de 1902-1906, a cidade fluminense foi remodelada para extinguir as heranças do seu passado monárquico e colonial, e alocar-se no grupo das grandes e modernas metrópoles mundiais. Ruas alargadas, portos saneados, construções de teatros e avenidas compunham o quadro de metas das grandes obras. 
Almejava-se uma nova identidade nacional através do Rio de Janeiro, caracterizando-o como uma cidade cosmopolita, racional, cientificamente planejada, ordenada, honrando as palavras escritas na bandeira nacional.

A impressão dos contemporâneos era que a Belle Époque era uma só. Mas essa certeza não passava de uma miragem (Cf. COSTA; SCHWARCZ, 2000: 72). A modernidade era imposta de cima para baixo. Elegeu-se uma cultura civilizada, em consonância com os modelos eurocêntricos, e um conjunto de comportamentos sociais definidos como progressistas. As vozes ativas nessas escolhas - e quem desfrutava dessas escolhas - eram as elites brasileiras. Estas pretendiam emparelhar-se com a inspiração francesa e, assim, ganhar ares cosmopolitas; almejavam fazer parte daquele mundo que parecia funcionar em outra frequência, tão distante das camadas mais pobres da população, das cidades de ruas estreitas, do mau cheiro das zonas portuárias. Tornava-se pertencer ao grupo das grandes potências civilizadas, aderir à marcha da humanidade, adquirir a cultura universal dos bons hábitos e das boas letras, absorver o que estava no mundo (Cf. NEEDELL, 1993).

Para a legitimação dessa missão civilizatória, destacam-se os intelectuais ${ }^{4}$. Estes não escaparam ao processo civilizatório sofrido pelas cidades, servindo aos seus interesses à medida que deixavam, desde a década de 1870, seus lugares marginais e eram elevados à categoria de elite cultural ${ }^{5}$. Ocupando lugares sociais calcados na urbanidade dos grandes centros e engajados na vida pública do país, formaram as "cidades das letras", associando-se ao poder institucionalizado no alvorecer do século XX (Cf. RAMA, 1985). Atraídos aos quadros do Estado por ter neste o único distribuidor de bens simbólicos e materiais, os intelectuais brasileiros estariam à frente de todo um processo uniformização cultural da nação a partir dos padrões das elites, imbuídos de um forte caráter pedagógico, para a construção da modernização nacional.

\footnotetext{
${ }^{4} \mathrm{O}$ conceito de "intelectual" utilizado no presente artigo baseia-se nos estudos do historiador francês Jean-François Sirinelli, segundo o qual aqueles eram indivíduos engajados em suas respectivas sociedades, atuando como críticos e formadores de opinião. Os intelectuais, segundo Sirinelli, formariam pequenos grupos, de contornos vagos e mutáveis. (Cf. SIRINELLI, 2003: 242-243).

${ }^{5}$ A figura do literato boêmio visto nos cafés e bares de terno puído, em contato com meretrizes e capoeiras, foi substituída pela imagem do escritor elegante, envergando chapéu-coco e monóculo, frequentador dos salões e das rodas de leitura. Surgia a "boemia dourada" (Cf. BROCA, 2004: 57-66). Os que não se adequavam ou não eram cooptados pelos diferentes grupos que se formaram, têm o seu acesso negado às altas rodas e relegado à vida desregrada. Excluídos, não integravam a "elite cultural" do país, geograficamente localizada na cidade do Rio de Janeiro, possuindo ressonância e amplificação de suas ideias, segundo as categorias estabelecidas por Jean-François Sirinelli para definir o grupo.
} 
O grupo de intelectuais brasileiros era composto por indivíduos localizados em sua maioria nos centros urbanos. Esses homens possuem uma trajetória semelhante, de maneira geral: passagens pelas escolas de direito, engenharia ou medicina; profissões enquadradas no funcionalismo público, no jornalismo ou no magistério; exercício de atividades, de forma frequente ou esporádica, nos órgãos da imprensa. Suas redes de sociabilidade eram tecidas nas redações de jornais e revistas, ou em instituições, como a Academia Brasileira de Letras, onde empreendiam movimentos de adesão ou repulsa, de amizade ou inimizade.

O nacionalismo, no entanto, foi o vetor partilhado por essa intelectualidade do início odo século XX, para problematizar a comunidade imaginada brasileira. Atormentava a pergunta sobre quais seriam os valores propositores da sua integração territorial, moral e social; afinal, qual seria a sua natureza. Tais questionamentos prestavam-se a dois objetivos pragmáticos e políticos: o primeiro dizia respeito à formação de uma cultura nacional, una e indivisível; o segundo pretendia identificar as mazelas brasileiras e saná-las.

A criação cultural do Brasil por seus intelectuais seguia os paradigmas característicos da Belle Époque. A cultura brasileira, segundo esses pensadores, era centrada na urbanidade das grandes capitais, tendo o Rio de Janeiro como parâmetro, e nos modelos dominantes na Europa, preferencialmente a França. O rural e o regional ganhavam status de folclore, registro de uma manifestação fadada ao desaparecimento pelo alastramento do implacável progresso. Pretendiam a padronização cultural do país de acordo com uma "alta cultura", baseada nas disposições de uma minoria, transformando-a em regra (Cf. GELLNER, 1998: 6).

As diferentes correntes que movimentaram a intelectualidade procuravam, também, descobrir e solucionar as deficiências que atravancavam o progresso do país. Para tanto, era imprescindível a construção de um conhecimento sobre o Brasil e sua difusão, consonante com as propostas cientificistas da modernidade. A ignorância do povo em relação à sua história, geografia e língua, buscava-se redimir. Elaboraram, dessa forma, projetos políticos-culturais para regenerar a nação, a partir do entendimento dos seus pontos erráticos, sustentando o reconhecimento de sua identidade cultural e de sua civilidade.

Tais certezas absolutas em relação ao progresso e à civilização foram, porém, interrompidas pelo tiro que matou o arquiduque Francisco Ferdinando, no dia 28 de junho de 1914. A bala disparada pelo estudante sérvio rasgou a tela impressionista que mostrava um mundo em cores, interrompendo toda uma cadeia de pensamento. Apesar da distância oceânica 
que separava o Brasil do teatro da Primeira Guerra Mundial, o país foi afetado moralmente. Viu ruir os alicerces no qual baseou a sua evolução.

\section{Ferro e fogo}

A morte do herdeiro do trono austro-húngaro desencadeou uma série de ações dos países europeus, que os levaram a se afundarem em trincheiras nos quatro anos seguintes. $\mathrm{O}$ fato do assassino do arquiduque pertencer a uma organização sérvia levou a Áustria-Hungria a declarar guerra àquele país. Atrás da Sérvia, veio a Rússia, mobilizando exércitos em suas fronteiras e alarmando a Alemanha, que, após ter o seu ultimato ignorado pelos russos, declarou guerra ao país de Nicolau II.

Os tratados de aliança assinados pelas principais potências europeias ao final do século XIX e início do século XX trouxeram os demais personagens para o centro do teatro da guerra. Em 1882, Alemanha, Áustria-Hungria e Itália firmaram um acordo de apoio mútuo em caso de agressão a uma das partes por outros países, formando a chamada Tríplice Aliança ${ }^{6}$. Alguns anos mais tarde, em 1907, Rússia, Grã-Bretanha e França uniram-se numa coalizão militar denominada Tríplice Entente, formalizando, assim como a sua oponente, amparo recíproco em caso de enfrentamento bélico.

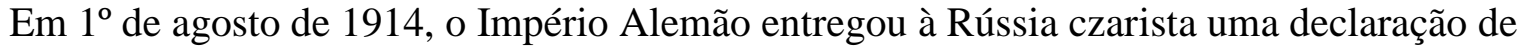
guerra. Naquele gesto culminavam anos de corrida armamentista, rivalidades industriais, alianças secretas, lutas por independência e disputas colonialistas. A Belle Époque escondia em seus teatros de revista e nas maravilhas da tecnologia um panorama de tensão política, com uma disputa ferrenha em torno, simultaneamente, da manutenção e da mudança do status quo na geopolítica mundial, paulatinamente alterado. Os anos de crença numa paz eterna foram como a calmaria que antecipa a tempestade.

$\mathrm{O}$ início da conflagração europeia suscitou uma rápida resposta do governo brasileiro. $\mathrm{O}$ presidente Hermes da Fonseca de pronto declarou a neutralidade do Brasil diante dos blocos em conflito, atitude justificada pelas relevantes relações comerciais mantidas tanto com a GrãBretanha, quanto com a Alemanha, numa fase em que o desempenho econômico e financeiro

\footnotetext{
${ }^{6}$ O Reino da Itália, já em 1914, abandonou a Tríplice Aliança, anunciando neutralidade no conflito. O Império Otomano, por sua vez, aderiu ao bloco de beligerantes liderado pela Alemanha, declarando guerra aos países aliados.
} 
brasileiro enfrentava sucessivas crises. $\mathrm{O}$ decreto que oficializou o posicionamento brasileiro na guerra demonstra qual era a maior preocupação do país: a intenção de manter intacto o intercâmbio comercial brasileiro com a Europa ${ }^{7}$.

Se o governo brasileiro entendia a beligerância de maneira pragmática, os jornais cariocas apresentavam questões de outra natureza. Um intenso debate entre intelectuais a respeito dos acontecimentos e, principalmente, sobre o posicionamento brasileiro, em meio aos desdobramentos daquela guerra sem precedentes, desenrolava-se nas páginas dos periódicos. Pronunciando-se por meio de cartas e artigos endereçados às redações, por pseudônimo ou assinados, os homens de letras manifestavam-se para aprovar ou desaprovar as motivações e desempenhos deste ou daquele lado, e para refletir a respeito dos impactos da conflagração sobre o país. A partir desses discursos, percebe-se o quanto a beligerância desenrolada na Europa gerava expectativas sobre o Brasil.

Já no mês de agosto de 1914, escritos emitindo opiniões sobre a guerra foram publicados nos jornais cariocas $^{8}$. O primeiro impacto demonstrava reações parecidas, que iam da perplexidade à reprovação. O escritor Antônio dos Reis Carvalho (? -1947), em artigo publicado dez dias após o início do conflito, expunha uma crítica contundente a alguns dos valores transmitidos pela Belle Époque que levaram o país, principalmente ao cientificismo e o racionalismo exacerbado. Para o bem da sociedade, defendia a moralização do conhecimento, o apreço pelo cultivo das boas emoções, como explicou a seguir: "Não basta, pois, a instrução, a cultura do espírito, para ser feliz. O bem estar dos indivíduos e das sociedades depende antes de tudo da sociabilidade; é função do altruísmo." (CARVALHO, 1914: 2). Seguindo essa linha de raciocínio, Reis Carvalho desenvolveu uma profunda crítica aos países beligerantes, que se preocuparam em desenvolver a ciência, mas esqueceu-se de cultivar o espírito. Afirmou:

Dezoito milhões de homens, que, na sua maioria sabem ler e escrever - devem ter-no aprendido obrigatoriamente nos seus países militarizados - de que grande parte possui a cultura especialista das ciências e artes matemáticas e físicas, pois só assim são capazes de manobrar essas máquinas assombrosas que perlustram [sic] os oceanos, penetram-lhe as profundezas ou se alçam à imensidade do céu, dezoito milhões de homens, ufanos de pertencerem a países civilizados, governados por indivíduos mais ou menos cultos, dão ao mundo o

\footnotetext{
${ }^{7}$ O decreto que estipulou a neutralidade brasileira na Primeira Guerra Mundial foi emitido em 4 de agosto de 1914, sob o n ${ }^{\circ} 11.037$.

${ }^{8} \mathrm{O}$ artigo irá centrar-se nos escritos publicados no Jornal do Commércio, uma vez que este era um dos mais tradicionais jornais nacionais no início do século.
} 
espetáculo da barbaria máxima, espalhando por toda a parte, a ruína, a desolação e a morte. (CARVALHO, 1914: 2)

Nem bem passado o primeiro mês do início dos enfrentamentos militares, no entanto, declarações de apoio a um dos blocos combatentes já eram expostas na imprensa. Em suas argumentações, discutia-se qual dos lados que se enfrentavam possuíam os motivos corretos para fazê-lo. Principalmente, nas mãos de quais nações residia o futuro da humanidade, ameaçada fatalmente pela guerra.

O intelectual sergipano Manoel Bonfim (1986-1932) manifestou claramente sua opinião favorável ao grupo da França, Inglaterra e seus coligados. Em artigo publicado no Jornal do Commércio, em 17 de agosto de 1914, Bonfim afirmou a culpabilidade do Império do kaiser Guilherme II. Seus argumentos para corroborar sua tese são significativos: ao invés da análise de fatos políticos e econômicos, o exame da natureza dos alemães, acrescido do largo uso de oposições entre estes e as nacionalidades aliadas.

A guerra teria sido provocada pela sede de poder da Alemanha, justificada de duas maneiras: pela liderança prussiana no processo de unificação alemão e pela péssima natureza do gênio teutônico. "Prússia maldita, que levou o Ocidente a afogar-se em sangue!" (BONFIM, 1914: 2), afirmou o articulista. O "prussianismo" na composição do Estado moderno alemão teria suplantado o desenvolvimento intelectual humanista na região, onde as filosofias de Kant e Goethe teriam sido substituídas pela lei da força e pelo militarismo do chanceler Bismarck (18151898) e do estrategista Von Moltke (1800-1981) ${ }^{9}$. A supremacia prussiana sobre a Alemanha teria reforçado características inerentes àquele povo, tais como inaptidão política, tendência ao isolamento, repulsa a trocas culturais, tirania e barbarismo. Estas características psicossociais, refletidas em sua organização social, política e trato com outras culturas, marcariam as discrepâncias entre esse povo e as nacionalidades aliadas - reunidas por Bonfim sob a denominação de "latina" -, configurando em seu oposto completo. A guerra, nas palavras do sergipano, seria "um desafogo; é a libertação, a cessação de um estado militar permanente, insustentável"; isso porque um povo semibárbaro preferiu resolver os seus casos pelo ferro e pelo fogo, e por ele, e contra ele, o Ocidente teve de armar-se" (BONFIM, 1914: 2).

\footnotetext{
${ }^{9}$ Prussianismo foi um conceito utilizado de maneira corrente ao longo da Primeira Guerra Mundial, marcando a influência da antiga Prússia sobre as diretrizes políticas, econômicas e mesmo culturais da Alemanha após a sua unificação, em 1871.
} 
No lado oposto da trincheira, encontrava-se Higino de Mello (? -?). Sua carta endereçada ao Clube Germânia, e divulgada na sessão "Publicações a pedidos", foi escrita apenas um dia após o artigo de Manoel Bonfim. No entanto, consistia em uma defesa do Império Alemão e uma crítica à maneira como a conflagração europeia estava sendo retratada no Brasil, detratando a líder da Tríplice Aliança.

Na carta, o remetente atacava tanto a imprensa carioca, quanto a Câmara dos Deputados por suas posturas tendenciosas diante da beligerância, favorecendo em suas ações e nas divulgações de notícias os países da Entente. Afirmou:

É lastimável que a imprensa diária, na sua generalidade, imbuída de proselitismo e de certa carência de cultura, destempere da sua missão, levando à massa inconsciente de seus leitores notícias suspeitas sobre a marcha dos negócios guerreiros no velho continente europeu. A Câmara dos Srs. Deputados, também, já fez aprovar uma moção inconveniente, como se esses representantes do sufrágio universal exprimissem a verdade do sentimento de uma nação governada exoticamente. (MELLO, 1914: 7).

Assim como Manoel Bonfim, Higino de Mello empreendeu uma análise do caráter do povo alemão, mas suas conclusões foram mais positivas do que as encontradas pelo sergipano. Sábios, vigorosos e superiormente evoluídos no tocante à indústria e à trajetória histórica, os germânicos iriam à guerra não para destruir a civilização, mas para salvá-la, ensinando ao mundo “o grande segredo que curará a sociedade moderna” (MELLO, 1914: 7). O aspecto salvacionista dos teutônicos se aplicaria principalmente ao Brasil, país atrasado e de povo ignorante, tendo nos imigrantes de origem teutônica os condutores para a sua evolução. A suposta detração pública que a Alemanha sofria influenciaria negativamente a populaça, instigando-as contra esses benfeitores.

As premissas usadas pelos dois articulistas repetiram-se no debate entre partidários da Tríplice Entente e defensores dos Impérios Centrais, ao longo dos anos da guerra. Para aqueles que apoiavam as nações aliadas, o confronto fora provocado pela Alemanha, cuja nacionalidade era marcada por aspectos morais negativos, sendo traduzido por um embate entre a civilização e a barbárie. Os dois blocos seriam, assim, racial e espiritualmente opostos. Já para os entusiastas da Tríplice Aliança, a guerra surgia sob um prisma diverso de interpretação. O Segundo Reich não atacava, mas defendia-se da cobiça anglo-francesa sobre os seus avanços econômicos e 
tecnológicos. Povo repleto de qualidades morais e intelectuais, seus apoiadores costumavam ressaltar a sua valiosa contribuição para a evolução nacional do Brasil ${ }^{10}$.

Nas páginas dos jornais cariocas, tais opiniões parciais ocorriam em maior número. Afinal, conforme se acreditava, eram os valores civilizacionais correntes até então que se enfrentavam nas batalhas europeias. Tamanho partidarismo culminou mesmo na fundação de duas ligas, cada uma defendendo um lado dos beligerantes: a Liga Brasileira pelos Aliados, partidária dos países da Entente, e a Liga Brasileira Pró-Germânia, defensora da Tríplice Aliança $^{11}$. Em meio a discussões apaixonadas, difícil mesmo era manter-se neutro.

\section{Abaixo as armas}

Apesar de consoante com a posição oficial assumida pelo governo federal, os discursos que assumiram um tom de neutralidade diante dos blocos beligerantes eram quantitativamente mais escassos do que aqueles que se posicionaram ao lado deste ou daquele combatente. Surgindo em maior número nos primeiros anos do conflito, foram rareando, à medida que o posicionamento do Brasil na guerra foi abandonando a neutralidade. O que não significa que tenham sido menos incisivos em suas afirmações.

Em 14 de agosto de 1914, o Jornal do Commércio publicou uma conferência pronunciada pelo advogado Rodrigo Octávio Langaard de Menezes na Biblioteca Nacional. A palestra era sobre Direito Internacional e Privado. No entanto, a então recente eclosão da Primeira Guerra ocupou boa parte de sua fala.

O tom de Rodrigo Octávio era de profunda decepção com os valores do progresso veiculados até então. O incremento da tecnologia, a evolução das formas jurídicas e o império da razão em nada pareciam ter contribuído, segundo o jurista brasileiro, para aplacar a "alma selvagem do ser humano" (OCTÁVIO, 1914: 3). Muito pelo contrário, ela aumentaria seu poder

\footnotetext{
${ }^{10} \mathrm{Na}$ discussão desenvolvida na imprensa em torno das nações que se enfrentavam no continente europeu, seus intercessores apressaram-se em delegar apelidos mútuos. Os que se colocavam ao lado da campanha da Tríplice Entente eram conhecidos como aliadófilos, enquanto os que abraçaram a causa dos Impérios Centrais eram chamados de germanófilos.

${ }^{11}$ A Liga Brasileira pelos Aliados foi fundada em março de 1915, por José Veríssimo, Eliseu Montarroyos e Graça Aranha, para delegar apoio moral e beneficente aos países da Entente no Brasil, mobilizando a opinião pública em favor desse bloco. Desta faria parte, inclusive, Antônio dos Reis Carvalho, anteriormente crítico dos estados de beligerância. A Liga Brasileira Pró-Germânia foi criada no mês de junho do mesmo ano, em associação com a colônia alemã no Rio de Janeiro, com os propósitos análogos aos de sua opositora, porém, dirigindo seu apoio à Tríplice Aliança.
} 
de destruição nesse embate inédito de uma nação contra a outra. A conflagração havia abalado a crença no progresso e demonstrava o quanto o homem ainda era primitivo. Afirmou o conferencista:

É essa lição da História: a consciência que ao homem empresta o desvendamento dos arcanos da ciência, o polimento que da cultura lhe advém, não lhe substituíram no fundo de seu organismo a alma do canibal que as presas revelam. A certos respeitos, parece que quanto maior é o grau de civilização de uma idade, menos consciência, mais desembaraço manifestam os povos no preparo da agravação das consequências da guerra. A guerra é uma competição de forças; é um símbolo; já foi singular (OCTÁVIO, 1914: 3).

A eclosão do conflito representava a interrupção da marcha progressista em que encontrava a humanidade, e a falência de certos valores. Mais do que isso, expunha o quanto esta ainda precisava evoluir, já que ao primeiro som do clarim, os homens abandonaram a evolução civilizacional para lutar. As metáforas utilizadas pelo palestrante demonstram esse entendimento da guerra como o encerramento brusco e traumático de um tempo. "Noite de pesadelo"; "cataclismo"; "chamas da destruição" foram algumas das denominações utilizadas por Octávio em sua palestra para denominar a guerra.

O desapontamento do advogado era direcionado, sobretudo, à Europa. O continente que aparentava ser o reduto mais evoluído da civilização ocidental, naquele momento, recorria a formas primitivas e bárbaras para a resolução de diferenças entre as suas nações. Se a região se afogava em sangue e ódio, a América, segundo Rodrigo Octávio, deveria manter-se afastada das batalhas e aprender, unida, com os erros europeus, rompendo com o seu modelo. Recém-chegada à jornada da História, e, segundo a sua lógica, menos contaminada pelos ímpetos da guerra, a América deveria forjar um novo paradigma de conduta nacional e internacional, e ensiná-las aos seus antigos colonizadores. Disse:

Acreditemos sinceramente que nascendo num momento em que a Humanidade tinha aparência de ser melhor, somos melhores por isso, e pertencemos a uma parte nova da criação que abdicou a essas práticas selvagens de que os povos, que se dizem mais civilizados, nos dão o deplorável exemplo. Reivindiquemos para nós esse estado de uma civilização mais próxima do ideal [...]. Sejamos o expoente representativo da cultura social; [...] trabalhemos calmamente e com método para criar para nós uma civilização nossa [...]. (OCTÁVIO, 1914: 3). 
Compartilhava da mesma opinião o jurista Clóvis Bevilácqua. Em conferência pronunciada no mesmo evento jurídico que Rodrigo Octávio, Bevilácqua apresentou concordâncias nos pontos principais da argumentação do seu colega quanto à Primeira Guerra, brevemente analisada em sua fala. Novamente, o estado de beligerância era interpretado como uma suspensão do progresso alcançado até então pelos homens e a falência dos valores cultivados pela Belle Époque: das ciências e artes às normas filosóficas e jurídicas. "É uma impressão de desmoronamento moral o que sentimos, em face do morticínio dos homens e da quebra dos princípios étnico-jurídicos", concluiu (BEVILÁCQUA, 1914: 3).

Bevilácqua reforçou, da mesma maneira, a necessidade de a América manter-se unida e apartada da situação belicosa. Era o momento de cultivar a esperança americana em um futuro diferenciado. Afirmou:

Tenhamos todos a mesma confiança e, fechando os ouvidos aos gritos de guerra que atroam as aves do outro lado do Atlântico, prossigamos na obra da paz, esperando que esta lição cruel consolide na América, a orientação da sua cultura desprendida de preconceitos guerreiros, e visando o bem estar da humanidade, pelo progresso econômico e intelectual, sob o patrocínio da justiça, ao impulso dos sentimentos benévolos. (BEVILÁCQUA, 1914: 3).

Em 1916, foi fundada por Teodoro Figueira de Almeida a Liga Americana pela Paz. A agremiação tinha por finalidade promover a união dos países americanos no cenário internacional, preparando-os para a nova conjuntura política que viria após a Grande Guerra. Sobre o confronto iniciado em 1914, a instituição possuía uma postura definida: ambos os lados combatentes encontravam-se isentos de razão. Ingleses, franceses, alemães ou turcos possuíam seus motivos, bem como a sua cota de erros no conflito, e, dessa forma, não possuíam superioridade sobre seus respectivos opositores. Em seu manifesto de abertura, declarou:

Certo as simpatias do nosso senso moral deverão estar do lado daqueles, sejam quais foram, que tiverem os seus territórios violados, os seus lares ocupados, as suas propriedades convertidas em celeiro e covil dos invasores. Mas tanto é verdade que na guerra é como na guerra que essas simpatias que hoje se inclinam por um lado amanhã penderão para o lado contrário, desde que os sucessos das armas oprimidas vençam as barreiras da resistência para atingir as regiões vitais do contendor e força-lo à rendição, pois que este é o objetivo comum dos exércitos. (ALMEIDA, 1916: 22). 
A Liga Americana pela Paz adentrou, inclusive, no debate em voga àquela época, no Brasil, sobre os diferentes estatutos da neutralidade, numa oposição entre "neutralidade ativa" e "neutralidade passiva". Essa discussão se dava em razão do discurso pronunciado pelo senador baiano Rui Barbosa (1849-1923) na Faculdade de Direito de Buenos Aires, em junho de 1916, conhecido posteriormente como "Deveres dos Neutros". O político brasileiro atacou veemente o que qualificou como "neutralidade passiva", em que os países mantenedores de uma postura neutral no conflito ignoravam as violações dos tratados internacionais assinados em convenções pelas nações beligerantes. Defendia, em contraponto, uma "neutralidade ativa", em que esses mesmos Estados neutros atuariam como autoridades policiais, reprovando e denunciando quaisquer descumprimentos das leis internacionais.

Nessas deliberações, a agremiação discordou de ambas as posturas. Se a "neutralidade passiva" ocorria em erro por tolerar atitudes ilegais por parte dos beligerantes, a "neutralidade ativa" poderia fomentar as rivalidades entre estes, bem como a adoção de julgamentos parciais. Assegurou:

Ora, se no terreno da seção positiva a "neutralidade ativa", ainda que honestamente observada, em nada concorreria para a solução do problema, e, porventura, só alcançaria complica-lo, por uma excitação geral do orgulho e do amor próprio, num debate infernal das partes magoadas; no domínio das suas conclusões o seu trabalho seria inútil, porque nada mais faria do que confirmar este brocardo secular da experiência da humanidade: "na guerra é como na guerra”, onde ela impera, ai está o crime! (ALMEIDA, 1916: 23).

Apresentando um programa pacifista em sua essência, a Liga pretendia, assim como os discursos de Rodrigo Octávio e Clóvis Bevilácqua, defender a exclusão do continente americano do teatro de guerra e a construção de uma postura política independente da Europa, unindo todos os Estados americanos em uma ação comum. A união americana seria imprescindível não apenas para fortalecer cada um dos países internamente, mas para apresentar uma nova era das relações internacionais, onde assumiria uma postura de liderança. Pregava o seu manifesto:

Assumindo, desde então, na sua plenitude, a missão civilizadora que os destinos da humanidade lhe reservaram, a América entraria triunfante no cenário da politica europeia, para retribuir, com os seus serviços civilizadores, os benefícios inestimáveis que recebeu do velho mundo. E do problema restrito, que seria a solução das dificuldades originais do atual conflito, o seu programa se elevaria mais alto, visando, em conjunto, a reparação dos erros políticos do 
passado europeu, de forma a assegurar a paz definitiva do Ocidente (ALMEIDA, 1916: 23).

Nos três posicionamentos acima expostos a respeito da Primeira Guerra, percebe-se a vinculação do discurso a favor da neutralidade com a ideia do pan-americanismo. Surgido ao final do século XIX e encabeçado pela Doutrina Monroe estadunidense, tal corrente de pensamento recrudesceu com a eclosão do conflito na Europa. O abalo dos modelos civilizacionais e políticos oriundos do continente em beligerância estimularam os países americanos - sobretudo sul-americanos - a se voltarem para uma tentativa de encontrar soluções e paradigmas intrarregionais. A representação da América como o epíteto de uma nova civilização, de condutas inéditas também são atreladas a essas falas. Não impunemente, em diversos momentos, seus autores utilizam os conceitos de "Novo Continente" e "Velho Continente" para se referirem, respectivamente, à América e à Europa.

Além da adesão ao pan-americanismo, as afirmações a respeito da manutenção da neutralidade no conflito envolviam a valorização da autonomia do Brasil em sua política internacional e um reclame às constantes intervenções dos países combatentes nas transações comerciais. O prolongamento inesperado dos anos de conflagração levou ambos os blocos inimigos a tentarem se sufocar economicamente, por meio do impedimento das suas ligações comerciais exteriores. Os países que assumiram a isenção na guerra foram essencialmente prejudicados, tendo suas cargas apreendidas e seus navios mercantes impedidos de atracarem em alguns portos europeus ou mesmo transitarem livremente.

A afirmação da neutralidade adquiriu, assim, um teor de protesto contra tais medidas, bem como uma afirmação da independência brasileira em suas relações exteriores. Com essas argumentações, F. F. de Alcântara publicou uma série de artigos no Jornal do Commércio, ao final do ano de 1916. Defendia o direito do Brasil em manter-se neutro na guerra e assim ser tratado pelos países em confronto, tecendo duras críticas ao governo federal por aceitar passivamente as imposições dos beligerantes, sobretudo dos Aliados. Afirmou:

Escrevendo estas linhas que nada mais significam que um grito de protesto de um espírito independente, contra a subserviência que nos diminui e amesquinha, desejaria que o meu Governo refletisse melhor sobre as nossas grandes responsabilidades, presentes e futuras, se reintegrasse na atitude compativel com os nossos brios tradicionais de país novo, mas altivo, e fizesse respeitar a 
linha de uma verdadeira neutralidade, salvando-nos, assim da humilhante CURATELA que nos querem impor. (ALCÂNTARA, F. F., 1916: 11).

As manifestações a favor de uma postura neutral foram rareando com o envolvimento cada vez maior do Brasil na guerra. Em abril de 1917, o país rompeu suas relações diplomáticas com a Alemanha, após o afundamento do navio mercante brasileiro "Paraná" por submarinos alemães. A partir desse mês, declarações partidárias da neutralidade tornaram-se ainda mais escassas, em vista da eminência da entrada brasileira na guerra. No entanto, não cessaram por completo.

O diplomata Oliveira Lima foi uma das poucas vozes a se levantar pela manutenção do estado de neutralidade. Ainda no mês de abril, alguns dias após o rompimento das relações germano-brasileiras, Oliveira Lima endereçou um apelo ao presidente da República, Wenceslau Brás, e ao ministro das Relações Exteriores, Nilo Peçanha, apelando para a exclusão do Brasil do conflito. Evocando a opinião pública nacional ao longo do seu manifesto, afirmava que a guerra havia cessado as liberdades individuais. As exposições a favor deste ou daquele bloco de beligerantes eram fruto de paixões irracionais e partidarismos políticos, que impediriam o entendimento dos erros cometidos por ambos os combatentes. E categorizou:

Se obedecemos docilmente às injunções de um dos lados, menos autoridade nos fica para rebelar-nos contra as injunções do outro lado, porquanto todas estas injulções envolvem desrespeito de princípios fixos e tradicionais, que já faziam parte do patrimônio moral da humanidade. (LIMA, 1917: 6).

Apelo feito em vão. O Brasil declarou guerra à Alemanha em 18 de outubro de 1918, sendo o único país sul-americano a atuar como beligerante na Primeira Guerra Mundial.

\section{Conclusão}

Os discursos a respeito da guerra possuem o claro objetivo de movimentarem a opinião pública brasileira. Em um momento em que a vendagem de jornais aumentava e o jornalismo surgia como profissão rentável, a imprensa surgia como um importante veículo para autopromoção e divulgação de ideias. Aliadófilos, germanófilos ou partidários de uma posição neutra faziam uso de diferentes estratégias de argumentação e linguagens para convencerem 
leitores de suas afirmações, numa guerra que, pela primeira vez, usou em larga escala a propaganda como instrumento.

Além disso, a Primeira Guerra Mundial apresentou-se como o momento de embate entre os intelectuais dos valores veiculados até então pela Belle Époque. Os modelos civilizacionais e nacionais oriundos da Europa eram seriamente contestados, uma vez que teriam desembocado no terrível estado de beligerância que assombrou o continente e o mundo. Alguns se apegaram aos antigos preceitos, outros buscaram a formulação de conceitos novos. No entanto, fosse qual fosse a posição assumida no debate, todos concordavam em uma categoria: uma conjuntura inédita seria inaugurada ao final da guerra, e era dever do Brasil assumir uma postura relevante no novo panorama.

\section{Referências Bibliográficas}

ALCÂNTARA, F. F. A neutralidade do Brasil (com vistas ao Exmo. Senhor Presidente da República e ao Congresso Nacional). Jornal do Commércio. Rio de Janeiro, 15 de setembro de 1916, p. 11.

ALMEIDA, Theodoro Figueira de. Os novos destinos da América. Conferência realizada na sede da Federação Operária do Rio de Janeiro pelo Dr. Theodoro Figueira de Almeida, autor da "A Missão Americana" e fundador da "Liga Americana pela Paz". Jornal do Commércio. Rio de Janeiro, 12 de outubro de 1916, p. 22.

ANDERSON, Benedict. Comunidades Imaginadas. São Paulo: Companhia das Letras, 2008.

BEVILÁCQUA, Clovis. A repercussão da guerra no Brasil. Jornal do Commércio. Rio de Janeiro, 21 de agosto de 1914, p. 3.

BONFIM, Manoel. A obra do germanismo. Jornal do Commércio. Rio de Janeiro, 17 de agosto de 1914, p. 2.

CARVALHO, Antônio dos Reis. A instrução e a guerra. Jornal do Commércio. Rio de Janeiro, 11 de agosto de 1914, p. 2.

CERTEAU, Michel. A escrita da história. Rio de Janeiro: Forense-Universitária, 1982. . "História, ciência e ficção". In: História e Psicanálise. Belo Horizonte: Autêntica, 2011. p. 45-70.

COSTA, Angela Marques da; SCHWARCZ, Lilia Moritz. 1890-1914: no tempo das certezas. São Paulo: Companhia das Letras, 2000.

GELLNER, Ernest. Dos nacionalismos. Lisboa: Editorial Teorema, 1998.

LIMA, Oliveira. A S. Ex. o Sr. Dr. Wenceslau Brás e ao seu ilustre ministro Dr. Nilo Peçanha - A situação. Jornal do Commércio. Rio de Janeiro. 10 de maio de 1917, p. 6.

MARTINS, Wilson. História da Inteligência Brasileira. São Paulo: Cultrix: Editora da Universidade de São Paulo, 1978. 
MELLO, Higino. Aos Ilmos. Srs. Presidente e sócios do Clube Germânia. Jornal do Commércio. Rio de Janeiro, 15 de agosto de 1914, p. 7.

Os novos destinos da América. Jornal do Commércio. Rio de Janeiro, 12 de outubro de 1916, p. 22-23.

OCTÁVIO, Rodrigo. A repercussão da guerra no Brasil. Jornal do Commércio. Rio de Janeiro, 14 de agosto de 1914. p. 3.

RAMA, Angel. A cidade das letras. São Paulo: Editora Brasiliense, 1985.

SIRINELLI, Jean François. "As elites culturais". RIOUX, Jean Pierre; Para uma história cultural. Lisboa: Editora Estampa, 1997. p. 347-390.

FGV, 2003. p. 231-269.

. "Os intelectuais". RÉMOND, Réne. Por uma história política. Rio de Janeiro: Editora

SKINNER, Quentin. Visões da política. Questões metodológicas. Lisboa: Editora DIFEL, 2005.

VINHOSA, Francisco Luiz Teixeira. O Brasil e a Primeira Guerra Mundial: a diplomacia brasileira e as grandes potências. Rio de Janeiro: IHGB, 1990. 